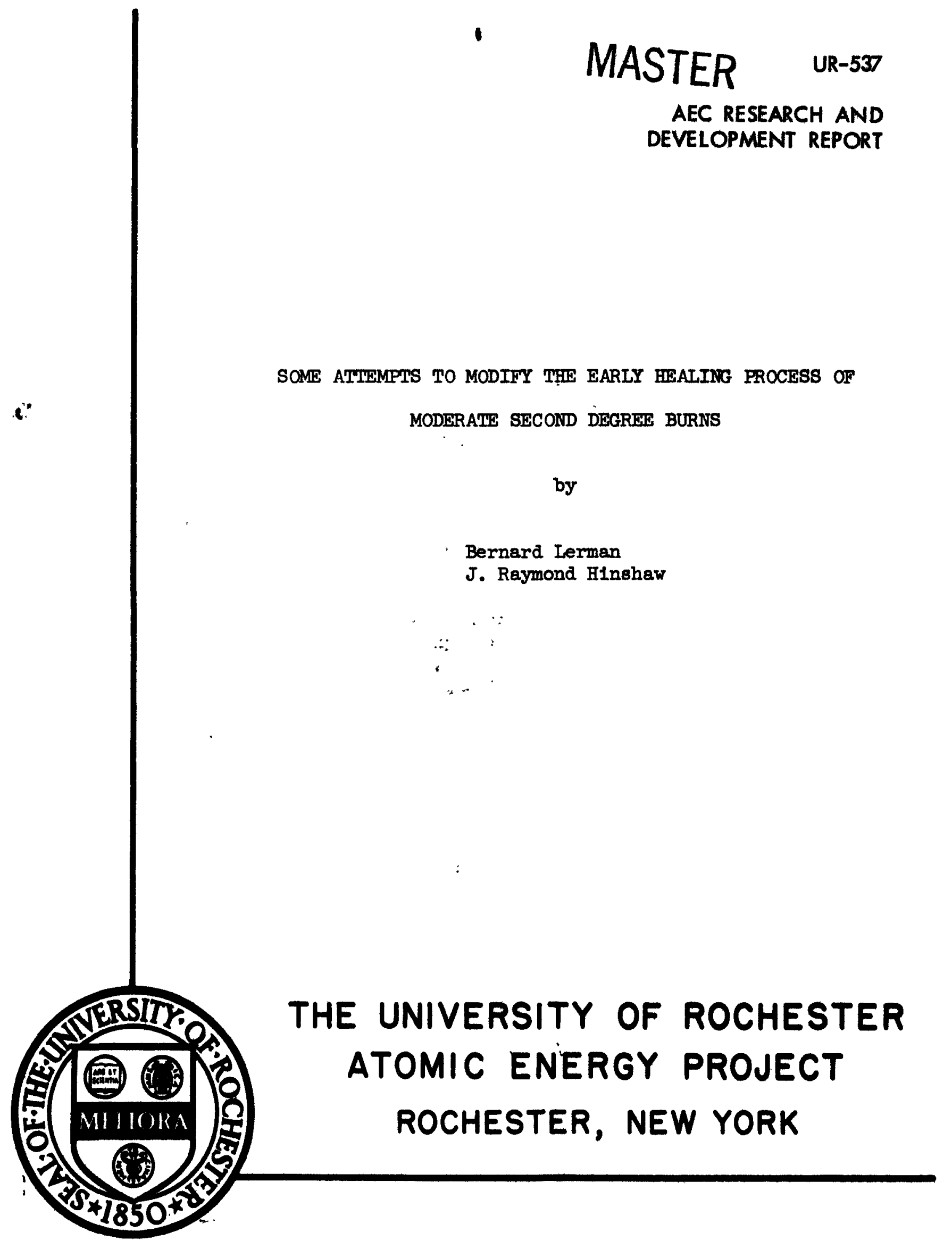




\section{IEGAI NOTICE}

This report was prepared as an account of Government sponsored work. Neither the United States, nor the Commission, nor any person acting on behalf of the Commission:

A. Makes any warranty or representation, express, or implied, with respect to the accuracy, completeness, or usefulness of the information contained in this report, or that the use of any information, apparatus, method, or process disclosed in this report may not infringe privately owned rights; or

B. Assumes any liabilities with respect to the use of, or for damages resulting from the use of any information, apparatus, method, or process disclosed in this report.

As used in the above, "person acting on behalf of the Commission" includes any employee or contractor of the Commission to the extent that such employee or contractor prepares, handles or distributes, or provides access to, any information pursuant to his employment or contract with the Commission. 


\section{DISCLAIMER}

This report was prepared as an account of work sponsored by an agency of the United States Government. Neither the United States Government nor any agency Thereof, nor any of their employees, makes any warranty, express or implied, or assumes any legal liability or responsibility for the accuracy, completeness, or usefulness of any information, apparatus, product, or process disclosed, or represents that its use would not infringe privately owned rights. Reference herein to any specific commercial product, process, or service by trade name, trademark, manufacturer, or otherwise does not necessarily constitute or imply its endorsement, recommendation, or favoring by the United States Government or any agency thereof. The views and opinions of authors expressed herein do not necessarily state or reflect those of the United States Government or any agency thereof. 


\section{DISCLAIMER}

Portions of this document may be illegible in electronic image products. Images are produced from the best available original document. 
UR-537

Biology and Medicine TID-4500, (14th Ed.)

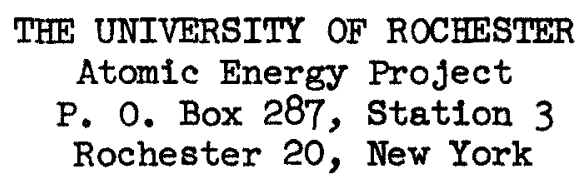

SOME ATTEMPTS TO MODIFY THE EARLY HEALTNG PROCESS OF

MODERATE SECOND DEGREE BURNS

by

Bernard Lerman

J. Raymond Hinshaw

Division: Special Programs s.

Section: Flash Burns

Date Completed: $12 / 4 / 58$
Division Head: H. A. Blair

Section Head: J. R. Hinshaw

Date of Issue: $1 / 30 / 59$ 


\title{
SOME ATIEMPTS TO MODIFY THE EARLY HEALTHG PROCESS OF \\ MODERATE SECOND DEGREE BURNS
}

\author{
Bernard Lerman \\ and \\ J. Raymond Hinshaw
}

\begin{abstract}
By the injection of hormones:and other agents which have been reported to influence scar formation, attempts were made to interfere with normal wound healing after the production of moderate second degree burns in pigs. It was hoped that some information on the development or prevention of hypertrophic scars and keloids might be gained from this experiment. Systemic administration of Doca, cortisone and toluidine blue, and local injection of cortisone, histamine and hyaluronidase nelther delayed healing nor altered significantly the histologic processes involved in the restoration of dermal tissues.
\end{abstract}


$\bullet$ 
It is generally agreed that hypertrophic scars and keloids are but different degrees of the same lesion. Delayed healing (due to infection, mechanical abrasion, embedded forelgn bodies, and full thickness skin loss WI thout graft coverage) almost invariably leads to hypertrophic scar formation and accounts for the majority of these unsightly defects. Certain individuals, however, respond to the most meticulous surgical incision or to the slightest puncture wound by the formation of a keloid, and this exaggerated accumulation of connective tissue may extend beyond the area of the initiating lesion. Because this untoward response to injury has been found in successive generations of the same family, a hereditary defect has been inferred. Because it may occur in one anatomical region and not in another of a susceptible individual, local factors have been implicated. Because it has been associated with a variety of experimentally induced hormonal imbalances, several hormones have been named the offending agents. The fact that the lesion is seen more frequently in the dark skinned races has raised the question of the role of melanin and of racial predisposition. In this laboratory the histologic remodeling of dermal collagen following a second degree burn was recently described. The processes 1llustrated lead to the restoration of lost tissue by tissue very nearly resembling normal dermis. In the experiment reported here, local and systemic injection of hormones and other agents which have been reported to influence scar formation were investigated for their effects on these local wound healing phenomena. The dosage and route of administration of those which failed to alter significantly the method or time of tissue repair in one species of animal (the pig) are described, and some possible reasons for their ineffectiveness are discussed. 
IETHODS

I. Ixperimental Design

Young Chester White pigs averaging 10 bilograms in weight were used as the experimental animals. They were anesthetized by the intraperitoneal infection of Dial in urethane (Ciba) in a dose of 65 milligrams per kilogram of body weight. The hair on each side of the pig was clipped and the skin was washed with a detergent solution. The heat source was a modified 24 inch Army carbon arc searchlight (1) which produces burns $1.7 \mathrm{~cm}$. in diameter. Since earlier work in our laboratory demonstrated that a radiant exposure of $10 \mathrm{cal} / \mathrm{cm}^{2}$ delivered in 0.3 sec。 will consistently produce moderate second degree burns, this radiant exposuremexposure time combination was emplojed. The burned areas were randomized so that there was equal probability of any one area being blopsied at any one of the selected tines given below. These biopsies, which included normal tissue on each side of the burn, were fixed in $10 \%$ formalin and stained with hematoxy in and eosin and with the modified Verhoeff's stain (2). Intravenous Nembutal (from 0.65 to 130 milligrams )was used as the anesthetic agent when the biopsies were taken.

II. Agents investigated

A. Systemic Doca (desoxycorticosterone trimethyl-acetate - Ciba). A $50 \mathrm{mgm}$. dose of Doca in oil was injected intramuscularly 2 weeks prior to the burning. On the day of burning and for eight days thereafter an additional daily dose of $25 \mathrm{mgm}$. of Doca in aqueous suspension was injected intramuscularly. At no time did the animal exhibit abnormal salt and water retention as evidenced by abnormal weight gain. The diet was the routine one used in this laboratory. In this animal 20 burns were produced and biopsies were taken on the 4 th, 7 th, 14 th and 21 st days after burning. The burn sites 
were inspected at these times for evidence of deviation from normal wound healing.

B. Local and systemic cortisone (Cortef - Tpjohn)

(a) Local treatments Forty eight burns were produced on one pig3 these were randomly divided into 3 groups of 16 . One group; used as a "control," received no treatment. In the second group, each of the 16 sites was injected locally with Cortef, approximately $13 \mathrm{mgm}$. In $1 \mathrm{cc}$. of sterile normal saline being used at each treatment. The solution was injected into the subcutaneous fat at the burn site on the day following burning and for 4 consecutive days. Each burn in the third group was injected at similar times, but $I$ ce。 of normal saline only was used. Areas were biopsied on the 4 th, 7th, llth or 2lst day following the burning.

(b) Systemic treatments sixty-four burns were produced on one pig. Two hundred mgm. of Cortef were injected intramuscularly (gluteal region) on the day of burning and on each subsequent day for 21 days. Areas were biopsied on the $7 t^{2}, 74$ th or 2lst day after burning. III. Toluidine Blue - (Used in an attempt to neutralize any effect of natural heparin). A gelatin capsule containing $200 \mathrm{mgm}$. of crystalline Toluidine Blue was given orally for 8 consecutive days. Twenty burns were produced on the day treatment was initiated, and biopsies were taken on the 4th, 7th, I4th and 21st day。 IV. Histamine - 48 burns were placed on one animal, and these were randomly divided Into three groups of 16 each. One group was used as a control; the second group was treated with local subcutaneous injection of 1 cc. of a 1816,000 solution of histamine: and each burn in the third group was injected subcutaneously with $I$ cc. of sterile normal saline. The injections were 
given for 4 consecutive days, beginning on the day of burning. Four blopsies from each group were taken on the 4 th, 7 th, 14 th and 21 st day. V. Hraluronidase - 48 burns were produced on one animal and these were divided randomly into 3 groups of 16 sites。 $150 \mathrm{TR}$ units of hyaluronidase (Infiltrase Armour Laboratories) were diluted in distilled water to $16 \mathrm{ccos}$ and 1 cco of this solution was infected subcutaneously under the burns of one group. One cc. of normal saline was injected under the burns in the second group, and the third group was not treated. The injections were again carried out for 4 consecutive days, beginning on the day of the burning, and the areas were biopsied on the 4th, 7 th, Ilth and 2lst day.

\section{RESULTS}

I. Systemic treatment with Desoxycorticosterone acetate (Doca). The ross appearance of the healing burns is entirely normal. Good eschar formation is noted on the 4th day after burning, with partial separation on the 7th day and full separation by two weeks. The burned sites are completely covered with new epithelium at the end of two weeks. Contraction of the healing burn is evident at two weeks, and by the end of the third week the area is linear.

Histologically, the four day old burns exhibit good demarcation of the tissue to be sloughed. Epithelial proliferation from the normal epidermis at the burn margins and from the undamaged hair follicles and dermal glands 1s beginning. Lateral to the bwrn, in the most superfielal dermis, the "spongy" lajer is beginning to appear. This spongy layer or cone of degradation of collagen has been described in previous reports from our Inboratoty (3), and for detailed description one is referred to these reports。 
By the 7th day, the slough is nearly separated, and epithelialization is practically complete. The new dermis is hyperplastic, with thicker and deeper rete pegs evident, and the spong layer is present just beneath the regenerating epidermis. Hyperplasia of the dermal glands is also noted.

On the llth day, the regenerated epidermis is markedly hyperplastic, being about 2 to 3 times the thickness of the adjacent normal epidermis. The long rete pegs extend Into the altered dermis and are thick and irregular. The spongy layer now is about $1 / 3$ to $1 / 2$ of the dermal depth. The hair follicles have regenerated, and small, new halrs are occasionally found. By the 2 lst day, the new epidermis has thinned and flattened out. Few rete pegs are seen, and none project deeply into the altered dermis. The spongy zone now involves practically the entire dermal thickness and is made up of a very loose network of fibroblasts, new collagen, caplliaries and mononuclear leucocytes. By this time skin thickness is fully restored.

The subcutaneous fat appears to be unaltered in all of the sections studied.

II. Local and Systemic Treatment with Cortisone. Grossly, wound healing progresses at a normal rate similar to that observed in the Doca treated pig. Histologically, in both the locelly and systemically treated animals, wound healing follows the normal sequence of events as described in previous reports (3). In the locally injected burn sites, whether cortisone or saline was used, tiny, deep dermal and subcutaneous abscesses are evident in the marity of tissue sections. These apparently have no effect on the rate or manner of healing except that they are progressively encapsulated with fibrous tissue.

III. The Toluidine Blue treated animal also showed no apparent disturbance in wound healing, either grossly or histologically. 
IV. Hilstamine and

V. Hyaluronidase. Local injections of both histamine and hyaluronidase produce no striking alteration in wound healing.

\section{DISCUSSION}

Although there is disagreement concerning histologic differences between keloids and hypertrophic scars, most authors agree that the distinction is a clinical one only. Numerous theories concerning the etiology of these lesions have been advanced, with hormonal factors, familial tendency, delayed epithelialization, excessive serous exudation in wounds, increased susceptibility by the individual, reaction to foreign bodies, skin pigmentation, a lack of tissue mast cells, and an increased heparin tolerance being considered as possiblities. Investigations of wound healing have also implied a role for such agents as hyaluronidase, heparin, and histamine.

Concerning keloid formation, Garb and Stone (4) belleved hormonal factors to be very important since the lesion is most common during the second decade when Increased hormonal activity is apparent. They listed of less importance race, familial tandency and delayed epithelialization. Yarshall and Rosenthal (5) implicated excessive serous exudate in wounds because chrontc edema leads to fibroplasia. Gathings (6) as well as Marshall reported on the use of kutapressin, a vasoconstrictor, for treatment of kelolds. Gesschichter (7) found Increased gonadotropic abstance and estrogen in a kelold plaque of fibrosis over the stomach of one of four monkeys treated with estrogen. Trusler and Bauer (9) believed that in addition to the above factors the anatomical area may be of some importance. They cite the fact that keloids occur most frequently in incisions which cross normal flexor creases and are uncommon in areas where skin tension is constantly changing. GIflcksmann (10) states that keloids or hypertrophic scars are due to a 
spreading, proliferative, inflamatory process elicited locally in sensitive persons by the presence of varlous particles acting as foreign bodies. Bloom (II) reviewed the Iiterature of familial cases and discussed the peculiarity of smallpox veccination in regard to stimulation of keloids.

Iversen (12a) noted a high incidence of keloids in acromegalics, and Seow (13) reported on the stimulating effects of growth hormone on collagen and protein content of skin in thyroidectomized rats. Taubenhaus and Amromin $(14)$ reported increased fibroplasia and formation of collagen fibrils in granulation tissue around turpentine abscesses after prolonged treatment of rats with desoxgcorticosterone and after growth hormone. PIrani, Stepto and Sutherland (15) investigated the effect of desoxycorticosteroids on connective tissue by studying healing abdominal wounds in guinea pigs. Increased amounts of granulation tissue with a lag in the maturation process of both cellular and intercellular elements was noted. The effect on immature connective tissue was marked, but was less apparent or absent on mature connective tissue.

Robinson and Hamilton (16) noted increased heparin tolerance after severe burns and in keloid formers during the healing phase. The role of heparin as an inhibitor of excessive fibroplasia was implied.

Cannon (17) and Harkins (18) found that while keloids developed in third degree burns not grafted, none oceurred in grafted areas. Block and Tsuzuki (19) reported a high incidence of scar keloids and hypertrophtc scars after healing of deep second or third degree flash burns. They felt that the mode of treatment, poor nutrition, high incidence of infection and delayed healing were important contributory factors.

Clarkson (20) in addition to the factors mentioned above considered the importance of skin pigmentation. (He also suggested the use of cortisone, after surgical removal of the keloid, as an adjunct to therapy.) 
Cornbleet (2l) recomended the use of local radiation and hyaluronidase prior to surgery to prevent recurrence of keloids. (It has also been reported (22) that hyaluronidase inhibits the formation of collagen fibers in fibroblast tissue cultures.)

Finally, Wichmann (23) reported a marked increase in mast cell count as healing progressed, with return to normal within three weeks. Robinson (16) and other workers reported a degranulation of mast cells in growing keloids and an almost complete absence of mast cells in scar tissue.

In this experiment the use of several agents which supposedly influence the formation or maturation of collagen had little influence on the healing of second degree burns in pigs. Only the animal treated with Doca showed much variation from average. Here, the "spongy layer" tended to involve most if not all of the dermis beneath the burned site, but this has been found in the past in some untreated animals.

There have been many reports of the inhibitory effects of cortisone on all components of the connective tissue and on wound healing (12c). In our experiment this was not demonstrated. Perhaps our experimental animal is Ittle affected by this hormone. Ragan (24) reported that the effect of cortisone on wound repair is less in the mouse, guinea pig and rat than in the dog, rabbit and man. It was, nevertheless, surprising to find so little effect from the local infection of this hormone.

We can attach little significance to the findings in this experiment that toluidine blue, histamine, and hyaluronidase treatments had no effect on the histologic nature or rate of healing of the burns. One can only say that their use in this experiment shed no light on factors involved in abnormal scar formation.

The amount of the agent employed in this study was based on therapeutic doses for humans (Doce, cortisone, and toluldine blue), corresponded 
to the minimum lethal pharmacological dose (histamine) or was chosen arbitrarily (hyaluronidase). However, there is no indication that either moderate increases in dosage or prolongation of treatment would have altered the results significantly。

In the pig, the type of burn produced in this experiment results in the early formation of an eschar. Epithelialization beneath the slough, which consists of the destroyed epidermis and superficial one-half of the dermis, is rapid. The resulting scar soon becomes pliable, and contraction of the damaged area occurs. Edema is minimal and disappears within a few days. There is no tendency to the formation of hypertrophic scars. Under these conditions, the use of the medications reported here offers little information concerning abnormal scar formation.

\section{CONCLUSIONS}

The histologic nature and rate of healing of moderate second degree burns in pigs was little altered by the systemic administration of either Doca or cortisones by local injection of cortisone, histamine or hyaluronidase; or by the oral administration of toluidine blue. In the dosages given, these agents, which have been reported to affect wound healing directly or indirectly, did not alter the local tissue reactions during the first three or four weaks after injwry. 


\section{BIBLIOGRAPHY}

1. Davis, T॰P॰, Krolak, L॰J., Blakney, R॰M०, and Pearse, H॰E., Modification of the Carbon Arc Searchlight for Producing Experimental Flash Burns.

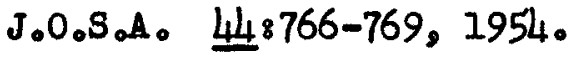

2. Hinshaw, JoR. and Pearse, $H_{\circ} E_{0}$, Histologic Techniques for the Differential Staining of Burned and Normal Tissues, Surg., Gyn. and Obst. $103: 726-730,1956$.

3. Payne, F.W. and Hinshaw, J.R., Histologic Studies of the Early Healing Process in Moderate Second Degree Burns. Univ. of Rochester Atomic Energy Project Report, UR-5]4, 1958.

4. Garb, Jo and Stone, M०J०, Keloids-Review of the Literature and a Report of Eighty Cases. Am. J. Surg. 58:315, 1942 .

5. Marshall, Wo and Rosenthal, So, Pathogenesis and Experimental Therapy of Keloids and Similar Neoplasms in Relation to Tissue Fluid Disturbances. Am. J. Surg. 62.8348-357, 1943

6. Qathings, J॰Go, The Treatment of Keloids with a Combination of Hraluronidase and Kutapressin. Am. J. Surg. 888429-430, 1954.

7. Gesschichter, CoF. and Lewis, D०, Tumors of Connective Tissue. Am. J. Cancer 25:630-655, 1935 .

8. Vargas, I., Jr., Attempt to Induce Formation of Fibroids with Estrogen, In the Castrated Female Rhesus Monkey. Bull. Johns Hopkins Hosp. $13: 23-30,1943$.

9. Trusler, $H_{0} M_{0}$ and Bauer, T.B०, Keloids and Hypertrophic Scars. Arch. Surg. $578539-552,1948$.

10. GIllcksmann, A., Local Factors in Histogenesis of Hypertrophic Scars. Brit。 J. Plastic Surg. 4888-103, 1951. 
11. Bloom, Do, Heredity of Keloids. Review of the Literature and Report of a Family with Multiple Keloids in Five Generations. NoI. State J. Med. $56.511-519,1956$

12a. Iversen, Kurt, Hormonal Influence on Connective Tissue. Connective Tissue in Health and Disease, p. 146. New York 1957, Philosophical Library Inc.

12b. pages $135-136$.

12c. - pages 130-135.

13. Scow, R.0., Effect of Growth Hormone on Muscle and Skin Collagen in Neonatal Thyroidectomized Rats. Endocrinology 49864l-656, 1951.

14. Tabenhaus, Mo, and Amromin, G.D., The Effects of the Hypophysis, Thrrold, Sex Steroids and the Adrenal Cortex upon Cranulation Tissue. J. Lab. and Clin. Hed. 3687-18, 1950.

15. Pirant, C.L०, Stepto, R,C. and Sutherland, $K_{0}$, Desoxycorticosterone Acetate and Wound Healing. Jo Exper. Med. 93:217-228, 1951.

16. Robinson, D.W. and Hamilton, T.R., Investigations into the Role of Heparin in Proliferative Tissue Reactions. Increased Heparin Tolerance in Patients with Burns and Keloids. Swrg. 348470-481, 1953.

17. Cannon, B., Procedure in Rehabilitation of the Severely Burned. In Management of the Cocoanut Grove Burns at the Massachusetts General Hospital, p. 103-110. Philadelphia, 1943, J. B. Ilppincott Co.

18. Harkins, HoN., The Treatment of Burns, po 177. Springfield, III., 1942, C. C. Thomas。

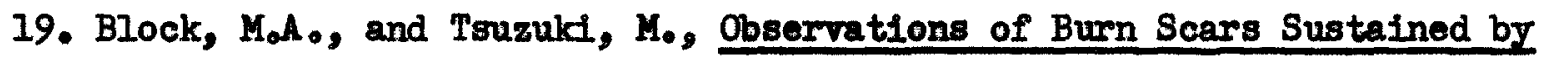
Atomic Bomb Survivors。 Am. J. Surgo $158417-438,1948$.

20. Clarkson, $P_{\circ}$, Cortisone as an Adjunct to Surgery in Treatment of Keloids. Lancet $18923-926,1953$. 
21. Cornbleet, T., Treatment of Keloids with Fyaluronidase. J.A.M.A. $154: 14,3$ Apr. 1954, p. 1161-3.

22. Robb-Smith, A.H.T., Normal Morphology and Morphogenesis of Connective Tissue. Connective Tissue in Health and Disesse, p. 28. New York, 1957. Philosophical Library, Ine.

23. Wichmann, B. The Yast Cell Count During the Process of Wound Healing: An Experimental Investigation on Rats. Acta Path. Microb. Scand. Suppl. $108,1-35,1955$.

24. Ragan, C. Connective Tissues. Trans. Third Conference, Josiah Macy Jr. Foundation, New York, 1952, p. 139. 